\title{
Alexander's Gate and the Unclean Nations: Translation, Textual Appropriation, and the Construction of Barriers
}

\author{
Benjamin Garstad \\ MacEwan University, Canada
}

We tend to think of translation as an exercise that crosses cultural boundaries, and quite naturally. The very word we use for the process indicates in its original tongue a 'carrying over' of the wealth of knowledge and beauty vested in one language to another. But I would like to consider here an instance in which translation and similar acts of literary acquisition and appropriation produced a contrary effect: the erection of barriers segregating one culture from others. The most important barriers are conceptual and metaphorical, but they are signalled by the description of the building of a very concrete barricade, the wall behind which Alexander the Great trapped the Unclean Nations. This episode was transferred from Syriac Alexander lore to the Apocalypse of Pseudo-Methodius and from there to one of the later versions of the Alexander Romance. The Apocalypse and the Alexander Romance were two of the most widely read and widely translated works in the Middle Ages, enjoying a truly international readership. Even as these texts crossed from one language and culture to the next, however, they changed the essential image of Alexander from one of a bold adventurer drawing new people within the ambit of his rule to one of a cautious protector who excludes strange and foreign races from his realm. This change in the image of Alexander reflects a fundamental shift in the attitudes and the strategy, the 'foreign relations approach', so to speak, of the Byzantine Empire, in whose reading culture the Apocalypse and the Alexander Romance both held a prominent place.

The Apocalypse falsely attributed to Saint Methodius of Patara was written in a moment of crisis. In 691 the caliph 'Abd al-Malik demolished the Byzantine church on the Temple Mount in Jerusalem and built the Dome of the Rock in its place. This act might suggest, as indeed it was intended to affirm, that the Arabs were not merely raiders, but that Muslim rule could be permanent. In response to dismay and apostasy, the author of the Apocalypse, perhaps from the Monophysite community at Singara, near Mosul, wrote to reassure his fellow Christians that the rule of the sons of Ishmael, as he calls them, would pass away as abruptly as it had arrived (Brock, "Syriac Views" 18-9; Reinink, "Pseudo-Methodius" 178-86; cf. Reinink, "Der edessenische" 33-4). ${ }^{1}$ Employing the device of typology, common in ancient Syrian hermeneutics, he showed that the sons of Ishmael (the Midianites) had overwhelmed the earth once before and been defeated by Gideon (Apoc. 5). ${ }^{2}$ Just so, they would be defeated by the Roman Emperor after a period of chastisement lasting seven (or ten) "weeks of years" (Apoc. 5.9).

\footnotetext{
${ }^{1}$ Reinink, Die syrische Apokalypse provides an edition of the Syriac text of the Apocalypse with a German translation and extensive commentary. The Greek and Latin texts of the Apocalypse, along with English translations, can be found in Garstad. The definitive edition of the Greek and Latin Apocalypses is Aerts \& Kortekaas.

2 On the typology in the Apocalypse, see Reinink, "Ismael".
} 
The Apocalypse was also written to remind its readers that, however cataclysmic the Arab invasions might seem, they did not represent the apocalypse predicted by Christ and His apostles. The true harbingers of the End of Days are the Unclean Nations led by Gog and Magog, who will issue from the north and devastate the whole world before one of the commanders of God's army defeats them in an instant (Apoc. 13.17-21). These Unclean Nations were first encountered by Alexander of Macedon on his campaign to the east (Apoc. 8.3-10). He recognized them as ugly and foul, especially in their appetites for unclean animals, corpses, and aborted fetuses, and he determined to prevent them from polluting the earth, and the Holy Land in particular. So he drove them into the inescapable "lands beyond the North" and after God, in answer to his prayer, drew the mountains together, Alexander fixed a bronze gate at the remaining gap to shut in the Unclean Nations until the consummation of the world.

The Ishmaelites are described as "children of the desert" who bring desolation in their wake (Apoc. 11.17). This means they are uncivilized and destructive, outside of the established community of nations. But the Unclean Nations are something else altogether. Their abominable practices reduce them to an almost inhuman level. It is not simply that they dwell outside of the civilized world, as the Ishmaelites do, but that the order of the world cannot be sustained unless they are excluded from it. The great virtue of Alexander is that he recognizes the danger posed by the Unclean Nations.

The Apocalypse of Pseudo-Methodius was originally written in Syriac, the Semitic tongue, the heir of Aramaic, which flourished as the liturgical and literary language of the Middle East's Christians. The Alexander episode in the Apocalypse depends on earlier Syriac works devoted to Alexander (Budge; Stoneman, Life in Legend 176-7). ${ }^{3}$ The crisis that precipitated the composition of the Apocalypse was felt beyond the orbit of Syriac speakers and readers, which always overlapped with the circle of Greek literacy. A Greek translation of the Apocalypse was quickly made, although we cannot say precisely when. We can, however, offer something of a date for the Latin translation, which was made from the Greek translation, rather than the Syriac original. The earliest manuscript of the Latin text can be dated to before $727 .{ }^{4}$ Through its Greek and Latin translations the Apocalypse and its distinctive image of Alexander achieved an influence which would have been impossible if it had remained in its native Syriac, although the Syriac text retained its currency for centuries and gained further readers in Armenian and Arabic translations. The whole Byzantine apocalyptic tradition was derived from Pseudo-Methodius, in Greek as well as in the other languages of the Byzantine Commonwealth (Alexander). There were at least two Old Slavonic translations of the Greek Apocalypse, perhaps in the late ninth century and again in the thirteenth or fourteenth century, and portions of the Apocalypse can be found in the Primary Chronicle and other Russian historical works (Cross; Cross \& Sherbowitz-Wetzor 184-5; Thomson 143-55). The extensive manuscript

\footnotetext{
3 The most thorough examination of the episode of the exclusion of the Unclean Nations and the construction of Alexander's Gate was for a long time Anderson, but now see also van Donzel \& Schmidt. Important supplements are Aerts, "Wondercoating"; Aerts, "Gog, Magog"; Doufikar-Aerts; Stoneman, Life in Legend 170-85.

4 The Codex Bernensis, Burgerbibliothek 611. See Verhelst 114 (\#4).
} 
tradition of the Latin text attests to its popularity in the West. ${ }^{5}$ There were also translations into the western vernaculars: German, French, Dutch, Catalan, and several English versions (Aerts \& Kortekaas 1: 34-5; cf. C. D'Evelyn). The Apocalypse was one of the few texts to transcend the linguistic divisions of Syrian, Greek, and Latin scholarship, as well as the doctrinal divisions between Monophysite and Chalcedonian and Latin Catholic and Greek Orthodox, to enter the consciousness of all medieval Christians.

The common assumption, I would imagine, is that the Zeitgeist of a given time is best revealed in the original compositions produced in that period, but the example of the Apocalypse of Pseudo-Methodius would seem to challenge this assumption. Translation, as an act of conscious selection, appears to have as much to tell us about historical events as original compositions, perhaps especially about how they were perceived by their contemporaries. A translation is a response to a certain situation or set of circumstances, the selection of a ready made answer seen as particularly appropriate to the most pressing concerns of a society, and the effort involved in rendering it from one language into another an indication of the premium placed on what a work has to offer. This certainly seems to be true of the Apocalypse, which was not only written, but also translated and retranslated in response to a bewildering and disconcerting crisis. At the very least, we learn from the Apocalypse of the desperate need for solace, hope, and some assurance of the permanence and continuity of the established order of things. But translation was not the only kind of literary and cultural acquisition to which the Apocalypse was subject. Successive generations copied the text for new readers who sought in it insights into the destiny of the world order and the significance of foreign invaders who disrupted it. And in a literary world where imitation really was the sincerest form of flattery - to say nothing of the most compelling claim to scholarship and authority - and plagiarism unheard of, passages were often lifted from the Apocalypse for insertion in other works of various genres.

The exclusion of the Unclean Nations behind the mountains of the North was excerpted in this way from the Apocalypse and included in the Alexander Romance, a largely fictional and often fabulous account of the life of Alexander the Great (Al. Rom. $\gamma$ iii.26). ${ }^{6}$ And it is clear that this episode specifically was selected for inclusion in the Romance, since the rest of the information on Alexander uniquely attested in the Apocalypse, such as that his mother, Chouseth, was an Ethiopian princess, and that he died childless, was rejected and does not appear in the Romance (Apoc. 8.2, 9.1). The incident of the Unclean Nations must have struck the redactor of the Romance as particularly resonant. It is inserted near the end of Alexander's career, at a point where earlier versions of the Romance had already begun to display an interest in limits and boundaries. After his return to Babylon from the wars, Alexander is said to have mounted a final expedition in the course of which

\footnotetext{
${ }_{6}^{5}$ Perry (xxxvii-xliii) lists the numerous manuscripts of the Latin Pseudo-Methodius in England alone.

${ }^{6}$ The best modern text of several versions of the Alexander Romance is Richard Stoneman's Italian edition: Stoneman, Romanzo di Alessandro I and Stoneman \& Gargiulo, Romanzo di Alessandro II. The third volume is eagerly awaited, but in its absence the standard edition of third book of the $\gamma$ recension remains Parthe; for the enclosure of the Unclean Nations, see Parthe 402-7. The best introductions to the study of the Alexander Romance are Jouanno and Stoneman, Life in Legend. Stoneman's 1991 Penguin translation is still an accessible entrée to the reading and enjoyment of the Romance.
} 
he arrives at the Pillars of Hercules (Al. Rom. $\alpha$ iii.27.3-4, ed. Kroll 128). His visit to the Pillars is also mentioned, as a culminating achievement, in the version of Alexander's last will and testament recorded in the Romance (Al. Rom. $\alpha$ iii.33.3, ed. Kroll 138; cf. Liber de morte testomentoque Alexandri Magni 107, ed. Thomas 38). But whereas the Pillars at the shores of the Ocean represent a natural barrier beyond which there is nothing, non plus ultra, Alexander's Gate at the mountains of the North is an artificial barrier erected by human effort and divine intervention beyond which is a populous land-one full of the menace of the other.

The Alexander Romance already had a long history when it assumed a passage from the Apocalypse of Pseudo-Methodius. The earliest elements of the Romance were probably prepared within a hundred years of Alexander's death in Ptolemaic Alexandria (Berg; Samuel 429; Burstein; Jasnow; Jouanno 57-125; Stoneman, Romanzo di Alessandro I xxviii-xxxii). Our earliest evidence of the composition as a whole, however, is the Latin translation of Julius Valerius, made between A.D. 270 and 330 from a Greek original for which we have only a single, scrappy manuscript witness (the $\alpha$ recension). ${ }^{7}$ The Greek Romance proved permeable, an 'open text' as David Konstan calls it, and some time after A.D. 500 a new version of the text was produced with a sufficient number of modifications, additions, and subtractions so as to constitute not a variant, but a different recension, the $\beta$ recension. ${ }^{8}$ The incident of the Unclean Nations is included in the severely abbreviated $\varepsilon$ recension and allows us to date the $\varepsilon$ recension to some time after 691 (Al. Rom. $\varepsilon$ 39.4-8, ed. Trumpf 144-8). ${ }^{9}$ From the $\varepsilon$ recension the enclosure of the Unclean Nations was taken over into the latest and fullest version of the Romance, the $\gamma$ recension (Al. Rom. $\gamma$ iii.26, ed. Parthe 402-7). ${ }^{10}$ In the $\gamma$ recension Alexander is much less the pagan hero of the $\alpha$ recension and far more a model of Christian kingship, an exemplum to the Byzantine emperor.

As complex and intriguing as the development of the various recensions is, it is not so impressive as the transmission of the Romance through translation. ${ }^{11}$ The Romance was first written in Greek, but our earliest evidence for the text is a Latin translation, corroborated by an Armenian translation. Translations were made not of one recension, but of the different ones as they developed, so that we have, in addition to Julius Valerius' Latin translation of the $\alpha$ recension, several versions of a Latin translation of the $\gamma$ recension attributed to Leo the Archpresbyter. ${ }^{12}$ The

\footnotetext{
7 The Greek text is edited in Kroll and the Latin of Julius Valerius in Rosellini, as well as both in Stoneman, Romanzo di Alessandro I and Stoneman \& Gargiulo, Romanzo di Alessandro II. See Stoneman, "Latin Alexander" 174-7; Jouanno 13-55.

${ }^{8}$ Edited by Bergson, also Stoneman, Romanzo di Alessandro I and Stoneman \& Gargiulo, Romanzo di Alessandro II. The $\beta$ recension is translated by Ken Dowden in Reardon 650-735. See Jouanno 247-303.

${ }^{9}$ See Jouanno 339-440.

${ }^{10}$ See Jouanno 441-65.

${ }^{11}$ Stoneman, Life in Legend 230-54, provides a comprehensive and meticulously annotated survey of the various versions and translations of the Alexander Romance, and the discussion in the following paragraph is based on his work. See also Zuwiyya.

${ }^{12}$ Leo's translation has not survived in its original form, and there are several variously manipulated and interpolated versions derived from it. Neither the Bamberg MS, closest to Leo's original and edited by Pfister, nor the $\mathrm{J}^{1}$ version of the Historia de proeliis, translated by Pritchard, include the enclosure of the Unclean Nations, but the later $\mathrm{J}^{2}$ version does; see Pritchard 8; cf. Cary 38-46, 130-31. Kratz makes Leo's work the basis of an interesting study of translation theory.
} 
Latin Romance was translated into most of the vernacular languages of western Europe, often on multiple occasions. ${ }^{13}$ A Syriac translation was made of the Greek Romance, which gave rise not only to distinctly Syriac versions (some including the story of the Unclean Nations), but also to translations in Arabic and Ethiopic. From the Arabic, further translations were produced in Farsi (and Alexander found a place in Firdawsi's Shah Nameb), Mongol, and Malay. From the frigid shores of the North Sea to the sweltering islands of the East Indies the adventures of Alexander found avidly receptive audiences. In an age often remarkable for its parochialism, the Alexander Romance was a truly international work, which crossed the boundaries of language, religion, and geography.

The capacity of the Romance to cross over into ever more disparate cultures makes the change worked in the Romance's presentation of Alexander by the inclusion of the Unclean Nations episode all the more ironic. But the exclusion of the Unclean Nations does perceptibly and significantly change the way Alexander is seen. In the earlier versions of the Romance Alexander is a conqueror and an adventurer who is forever crossing boundaries. Not only does he invade the Persian Empire and acquire its territory for his kingdom, he also ventures beyond the bounds of the civilized world into the unknown, encountering strange wonders and receiving the submission of exotic peoples, from the Romans to the Amazons. He passes beyond the confines of his world and integrates new peoples into it. This is an image of Alexander very much in the mode of one which has been popular in twentieth-century scholarship, having its greatest exponent in W. W. Tarn, that saw him fostering the 'brotherhood of mankind' and trying to establish an all-encompassing world state (Tarn, Unity of Mankind; Tarn, "Cynics and Stoics"; Tarn, Alexander the Great 2: 378-449; Stern 35-66; but for the rejection of this idea, see Badian; Baldry 113-28). The essential character of Alexander in the early Romance can be aptly expressed in terms of personality as outgoing.

The Alexander of the later versions of the Romance is not divested of his conquests and adventures, but the insertion of a new episode, the exclusion of the Unclean Nations, changes the complexion of his deeds and character. Alexander still crosses boundaries, but he also constructs boundaries. Rather than a conduit for the inclusion of barbarian peoples in the oikoumene, he makes barriers to keep them out - and the barbarians are depicted as so inhuman as to be incapable of integration anyway. Alexander becomes a protector of the Graeco-Roman establishment, not so much interested in extending it as in blocking the dangers that lurk outside of it. This new animosity is seen not only in the exclusion of the Unclean Nations, but also in Alexander's relations with the Egyptians. In the earlier versions of the Romance the Egyptians happily receive Alexander as their deliverer from the Persians and as their rightful king, but in the $\gamma$ recension the Egyptians resist Alexander and he must defeat them in war (Al. Rom. $\alpha$ i.34, ii.4.5-8; $\beta$ i.34; $\gamma$ ii.25.1-26.4). The building of the gate at the mountains of the North, however, remains the best example indicating that the character of Alexander has gone from being outgoing to introverted.

13 The most comprehensive treatment of the Alexander tradition in the medieval West is offered by the four hefty volumes of Gaullier-Bougassas. 
TranscUlturAl, vol. 8.1 (2016), 5-16.

http://ejournals.library.ualberta.ca/index.php/TC

This change in the presentation of Alexander is of more than merely antiquarian interest, however. In Byzantium Alexander was not seen as a remote historical figure, but as a model and guide to conduct, and as such he offers insight into the contemporary outlook of practically every age of Byzantine society. The Itinerarium Alexandri Magni was an account of Alexander tailor-made to present the example of the ancient king as a directive for current action. The Itinerarium was written around 340 expressly to encourage the emperor Constantius as he prepared for a campaign of his own against the Persians. ${ }^{14}$ It gave a brief account of Alexander's life and expedition based on Arrian's Anabasis and, to a much lesser extent, the Alexander Romance, as well as a now lost account of Trajan's campaigns in the East. The author of the Itinerarium set the dream of eastern conquests before the reigning emperor in the form of the example of Alexander. The De administrando imperio, a handbook on the nations surrounding the Empire and how to deal with them, written by the emperor Constantine VII Porphyrogenitus (r. 945-59) for the benefit of his son and heir Romanus II, demonstrates that even at the highest level Byzantine foreign relations continued to be informed by antiquarian learning. ${ }^{15}$ But the De administrando imperio also represents a profoundly different approach to foreign policy. Whereas the Itinerarium urged conquest and expansion, the De administrando imperio advised the ruler on the conduct of diplomatic relations, playing one restless neighbour off against another or bribing them to leave the Empire in peace, but generally maintaining the status quo.

The contrasting approaches of these two works can also be seen more broadly in the actual conduct of the Byzantine state at different phases in its history. Byzantium had, in its earliest centuries, been a multilingual, multicultural empire, which looked with confidence, not to say aggression, beyond its own borders. The Empire retained not unrealistic intentions of expansion or the reassertion of territorial claims, which were given substance in the reign of Justinian (r. 527-65) with the conquest of North Africa and Italy, and the will and ability to march into the heartland of an age-old foe and deliver a decisive blow, as when Heraclius defeated the Persians in 628. The disaster of the Arab invasions worked a perceptible change in Byzantine attitudes and ambitions. For centuries after that cataclysm, the Empire was on the defensive, intent on securing, rather than advancing its borders and preventing further losses, rather than acquiring new territory. The biographer of Basil I (r. 867-86) can congratulate his subject as a successful campaigner simply for holding his own against enemies at every point of the compass (Vita Basilii, 46-71, ed. Ševčenko 163-247). With practically all of the Empire's non-Greek-speaking lands shorn away by the Arab conquests, there was no more need to accommodate the Copts of Egypt or the natives of Syria. And there was less inclination to tolerate diversity of any sort. The 'other' was demonized and a ruthless determination to enforce conformity upon all deviant groups, pagans, heretics, and Jews, already evident before, became more pronounced.

\footnotetext{
${ }^{14}$ Edition: Tabacco Itinerarium; translation: Davies. See Barnes 135; Tabacco, “L’Itinerarium”; Lane Fox; Stoneman, "Latin Alexander" 177-80.

15 Edition and translation: Moravcsik.
} 
TranscUlturAl, vol. 8.1 (2016), 5-16.

http://ejournals.library.ualberta.ca/index.php/TC

One and the same catastrophe, the Arab invasions, seems to have occasioned the change in the Byzantine image of Alexander seen in the Apocalypse and the Romance and the change in the Byzantine conduct of external affairs. But there is more than a synchronicity between these two alterations; there also appears to be a correspondence in form and detail. Alexander raises an impregnable gate at a gap in the mountains to keep out the forces that imperil the purity and the integrity of the civilized world. Likewise, the method proposed by the Byzantine military manuals for dealing with the raids of the 'Hagarenes' or Arabs through the narrow passes of the Taurus mountains into the Anatolian interior was ideally to block them at whichever of those passes they attempted and debar them entry or, failing that, to close the pass as they tried to leave and attack them as they returned, weary and laden with booty (Leo, Tactica 119-20, 128, ed. \& trans. Dennis, Taktika 480-85; De velitatione 3-6, ed. \& trans. Dennis, Three Byzantine 155-63). ${ }^{16}$ In either case, the key to the strategy was the fortification of a mountain pass against invaders, which recalls Alexander's Gate. We even find a rare piece of evidence for the reading of the Alexander Romance in these very frontier regions, in the will of Eustathius Boilas (dated 1059), which catalogues his library and includes "the Alexander" (Vryonis 269; Lemerle 25, line 160). ${ }^{17}$ And the enemy Alexander excluded was luridly depicted as profoundly foreign, even inhuman. Just so, Byzantine society became more homogeneous in the aftermath of the Arab conquests, but also increasingly xenophobic and intent on a rigid conformity. The 'other' in the view of Byzantine society came more and more to resemble the Unclean Nations and to pose the same dangers of contamination and submersion.

The Alexander Romance was the repository of Alexander's memory in Byzantium, but that text, and so the memory, was not static, but dynamic. The introduction of a new anecdote from the Apocalypse of Pseudo-Methodius altered the image of Alexander in the Romance from that of an adventurous conqueror drawing new peoples into the fold to that of a careful protector guarding the borders and excluding strange races from his realm. This change in the memory of Alexander, which arose from the crisis of the Arab invasions, reflected a change in the strategy, and the underlying ambitions and attitude, of the Byzantine Empire. A policy of expansion and the extension of borders became, for centuries, one of retrenchment and the securing of borders to hold invaders at bay. The altered image of Alexander fixed these changes in a reality determined by authoritative precedents, for the Byzantines always kept an eye on the past and its significance for the present and the future. Perhaps an Alexander on the back foot helped to reconcile an empire on the defensive to the necessities of an irreversibly changed geopolitical situation. The great irony is that an extensive network of translations, which overleapt cultural and linguistic boundaries, and a voracious readership allowed this image of Alexander with its xenophobic and culturally exclusive tendencies to proliferate across much of the Old World. A process eminently capable of breaking down barriers built them up.

16 See Luttwack 308-10, 341; Haldon 363-6, 377-85. The origins of this frontier zone have been examined by Kaegi 1986.

17 Vryonis (269 n. 49) notes that this Alexander may be a religious book like all of the preceding titles, but the next item after the Alexander is "the Leucippe" (of Achilles Tatius), suggesting a transition to secular literature. Mango (240) identified the text in question as "an Alexander romance". 
TranscUlturAl, vol. 8.1 (2016), 5-16.

http://ejournals.library.ualberta.ca/index.php/TC

\section{REFERENCES}

Aerts, W. J. "Alexander's Wondercoating." Media Latinitas. A collection of essays to mark the occasion of the retirement of L. J. Engels (Instrumenta Patristica XXVIII). Ed. R. Nip, et al. Turnhout: Brepols, 1996. 159-67. Print.

."Gog, Magog, Dogheads and Other Monsters in the Byzantine World.” Gog and Magog: The Clans of Chaos in World Literature. Ed. A. A. Seyed-Gohrab, et al. Amsterdam/West Lafayette: Rozenberg/Purdue University Press, 2007. 23-36. Print.

Aerts, W. J. \& G. A. A. Kortekaas, eds. Die Apokalypse des Pseudo Methodius. Die ältesten griechischen und lateinischen Übersetzungen (Corpus Scriptorum Christianorum Orientalium, vv. 569-570. Subsidia, tt. 97-98). Louvain: Peeters, 1998. Print.

Alexander, Paul J. The Byzantine Apocalyptic Tradition. Berkeley: University of California Press, 1985. Print.

Anderson, Andrew Runni. Alexander's Gate, Gog and Magog, and the Inclosed Nations. Cambridge: The Mediaeval Academy of America, 1932. Print.

Badian, Ernst. “Alexander the Great and the Unity of Mankind.” Historia 7 (1958): 425-44. Print.

Baldry, H. C. The Unity of Mankind in Greek Thought. Cambridge: Cambridge University Press, 1965. Print.

Barnes, T. D. “Constantine and the Christians of Persia." Journal of Roman Studies 75 (1985): 126-36. Print.

Berg, Beverly. "An Early Source of the Alexander Romance." Greek, Roman and Byzantine Studies 14 (1973): 381-7. Print.

Bergson, Leif, ed. Der Griechische Alexanderroman, Rezension $\beta$. Stockholm: Almquist \& Wiksell, 1965. Print.

Brock, Sebastian. "Syriac Views of Emergent Islam." Studies on the First Century of Islamic Society. Ed. G. Juynboll. Carbondale: Southern Illinois University Press, 1982. 9-21. Print.

Budge, E. A. Wallis, trans. The History of Alexander the Great, being the Syriac version of Psendo-Callisthenes. Cambridge: Cambridge University Press, 1889. Print. 
Burstein, Stanley M. "SEG 33.802 and the Alexander Romance." Zeitschrift für Papyrologie und Epigraphik 77 (1989): 275-6. Print.

Cary, George. The Medieval Alexander. Cambridge: Cambridge University Press, 1956. Print.

Cross, Samuel Hazzard \& Olgerd P. Sherbowitz-Wetzor. The Russian Primary Chronicle: Laurentian Text. Cambridge: Medieval Academy of America, 1953. Print.

Cross, S. "The Earliest Allusion in Slavic Literature to the Revelations of Pseudo-Methodius." Speculum 4 (1929): 329-39. Print.

Davies, Iolo. “Alexander's Itinerary.” Ancient History Bulletin 12 (1998): 29-54. Print.

Dennis, George T., ed. \& trans. Three Byzantine Military Treatises. Washington: Dumbarton Oaks Research Library and Collection, 1985. Print.

ed. \& trans. The Taktika of Leo VI, rev. ed. Washington: Dumbarton Oaks Research Library and Collection, 2014. Print.

D’Evelyn, C. “The Middle-English Metrical Version of the Revelations of Methodius: With a Study of the Influence of Methodius in Middle-English Writings." Publications of the Modern Language Association of America 33 (1918): 135-203. Print.

Doufikar-Aerts, F. "Dogfaces, Snake-tongues, and the Wall against Gog and Magog." Gog and Magog: The Clans of Chaos in World Literature. Ed. A. A. Seyed-Gohrab, et al. Amsterdam/West Lafayette: Rozenberg/Purdue University Press, 2007. 39-52. Print.

Dowden, Ken, trans. "Pseudo-Callisthenes. The Alexander Romance." Collected Ancient Greek Novels. Ed. B. P. Reardon. Berkeley: University of California Press, 2008. 650-735. Print.

Garstad, Benjamin, ed. \& trans. Apocalypse of Pseudo-Methodius. An Alexandrian World Chronicle (Dumbarton Oaks Medieval Library, vol. 14). Cambridge: Harvard University Press, 2012. Print.

Gaullier-Bougassas, Catherine, ed. La fascination pour Alexandre le Grand dans les littératures européennes (Xe-XVI siècle). Réinventions d'un mythe. Turnhout: Brepols, 2014. Print.

Haldon, John. A Critical Commentary on the Taktika of Leo VI. Washington: Dumbarton Oaks Research Library and Collection, 2014. Print. 
Jasnow, Richard. "The Greek Alexander Romance and Demotic Egyptian Literature.” Journal of Near Eastern Studies 56 (1997): 95-103. Print.

Jouanno, Corinne. Naissance et métamorphoses du Roman d'Alexandre: Domaine grec. Paris: CNRS, 2002. Print.

Kaegi, Walter. “The Frontier: Barrier or Bridge?" Major Papers of the $17^{\text {th }}$ International Byzantine Congress. Washington: Aristide D. Caratzas, 1986. 279-303. (= Byzantine Warfare, ed. J. Haldon [Aldershot: Ashgate, 2007] 269-93). Print.

Konstan, David. “The Alexander Romance: The Cunning of the Open Text.” Lexis 16 (1998): 12338. Print.

Kratz, Dennis M. "Leo of Naples' Alexander Romance: Translation and Transformation." Mittellateinisches Jabrbuch 24/25 (1989/1990): 225-34. Print.

Kroll, Wilhelm, ed. Historia Alexandri Magni (Pseudo-Callisthenes), Volumen I. Berlin: Weidmannsche Buchhandlung, 1926. Print.

Lane Fox, R. J. “The Itinerary of Alexander: Constantius to Julian.” Classical Quarterly 47 (1997): 23952. Print.

Lemerle, Paul. Cinq études sur le XIe siècle byzantin. Paris: Éditions du Centre national de la Recherche scientifique, 1977. Print.

Luttwack, Edward N. The Grand Strategy of the Byzantine Empire. Cambridge: Belknap Press, 2009. Print.

Mango, Cyril. Byzantium: The Empire of New Rome. New York: Charles Scribner's Sons, 1980. Print.

Moravcsik, Gyulia, ed. Constantine Porphyrogenitus, De administrando imperio, trans. Romilly J. H. Jenkins. Washington: Dumbarton Oaks Center for Byzantine Studies, 1967. Print.

Parthe, Franz, ed. Der griechische Alexanderroman Rezension $\Gamma$, Buch III. Meisenheim am Glan: Verlag Anton Hain, 1969. Print.

Perry, A. Dialogus inter Militem et Clericum, Richard FitzRalph's Sermon: Defensio Curatorum', and Methodius: the Bygynnyng of the World and the Ende of Worldes, by John Trevisa. Early English Texts Society, no. 167. London: Humphrey Milford, 1925. Print. 
Pfister, Friedrich. Der Alexandrroman des Archipresbyters Leo. Heidelberg: Carl Winter's Universitätsbuchhandlung, 1913. Print.

Pritchard, R. Telfryn, trans. The history of Alexander's battles: Historia de preliis, The J'version. Toronto: Pontifical Institute for Mediaeval Studies, 1992. Print.

Reardon, B. P. Collected Ancient Greek Novels. Berkeley: University of California Press, 2008.

Reinink, G. "Ismael, der Wildesel in der Wüste. Zur Typologie der Apokalypse des PseudoMethodios." Byzantinische Zeitschrift 75 (1982): 336-44. Print.

"Der edessenische 'Pseudo-Methodius." Byzantinische Zeitschrift 83 (1990): 31-45. Print.

. "Pseudo-Methodius: A Concept of History in Response to the Rise of Islam." The Byzantine and Early Islamic Near East, I: Problems in the Literary Source Material. Ed. A. Cameron and L. Conrad. Princeton: Darwin Press, 1992. 149-87. Print.

- ed. Die syrische Apokalypse des Psendo-Methodius (Corpus Scriptorum Christianorum Orientalium, vv. 540-541. Scriptores Syri, tt. 220-221). Louvain: Peeters, 1993. Print.

Rosellini, Michaela, ed. Iuli Valerii res gestae Alexandri Macedonis translatae ex Aesopo Graeco. Stuttgart \& Leipzig: B. G. Teubner, 1993. Print.

Samuel, Alan E. "The Earliest Elements in the Alexander Romance." Historia 35 (1986): 427-37. Print.

Ševčenko, Ihor. Chronographiae quae Theophanis Continuati nomine fertur liber quo vita Basilii imperatoris amplectitur. Berlin: Walter de Gruyter, 2011. Print.

Stern, S. M. Aristotle on the World State. Oxford: Cassirer, 1968. Print.

Stoneman, Richard, trans. The Greek Alexander Romance. London: Penguin Books, 1991. Print.

-. "The Latin Alexander." Latin Fiction: The Latin Novel in Context. Ed. Heinz Hofmann. London \& New York: Routledge, 1999. 167-86. Print.

- Il Romanzo di Alessandro, Volume I, trans. Tristano Gargiulo. Milan: Fondazione Lorenzo Valla/Arnaldo Mondadori Editore, 2007. Print.

- Alexander the Great: A Life in Legend. New Haven: Yale University Press, 2008. Print. 
TranscUlturAl, vol. 8.1 (2016), 5-16.

http://ejournals.library.ualberta.ca/index.php/TC

Stoneman, Richard \& Tristano Gargiulo. Il Romanzo di Alessandro, Volume II. Milan: Fondazione Lorenzo Valla/Arnaldo Mondadori Editore, 2012. Print.

Tabacco, Raffaella. "L'Itinerarium Alexandri. Analisi del proemio." La storiographia latina del IV secolo D.C. Ed. Italo Lana. Torino: G. Giappichelli Editore, 1990. 147-62. Print.

ed. Itinerarium Alexandri. Firenze: Leo S. Olschki, 2000. Print.

Tarn, W. W. Alexander the Great and the Unity of Mankind. London: Humphrey Milford, 1933. Print.

—. "Alexander, Cynics and Stoics." American Journal of Philology 60 (1939): 41-70. Print.

- Alexander the Great. Cambridge: Cambridge University Press, 1948. Print.

Thomas, P. H., ed. Incerti auctoris Epitoma rerum gestarum Alexandri Magni cum Libro de morte testamentoque Alexandri. Leipzig: B. G. Teubner, 1960. Print.

Thomson, F. "The Slavonic Translations of Pseudo-Methodius of Olympu Apocalypsis." Kulturno razvitie na bulgarskata durzhava: krajat na XII-XIV vek: chetvurti Mezhdunaroden simpozium Veliko Turnovo, 16-18 oktomvri 1985. Ed. A. Davidov, et al. Sofia: Bulgarskata akademiia na naukite, 1985. 143-73. Print.

Trumpf, Jürgen, ed. Vita Alexandri regis Macedonum. Stuttgart: B. G. Teubner, 1974. Print.

Van Donzel, Emeri \& Andrea Schmidt. Gog and Magog in Early Syriac and Islamic Sources: Sallam's Quest for Alexander's Wall. Leiden \& Boston: Brill, 2009. Print.

Verhelst, M. "Pseudo-Methodius, Revelationes: Textgeschichte und kritische Edition. Ein LeuvenGroninger Forschungsprojekt." The Use and Abuse of Eschatology in the Middle Ages. Ed. W. Verbeke, D. Verhelst, and A. Welkenhuysen. Leuven: Leuven University Press, 1988. 112-36. Print.

Vryonis, Speros. "The Will of a Provincial Magnate, Eustathius Boilas (1059)." Dumbarton Oaks Papers 11 (1959): 263-77. Print.

Zuwiyya, Z. David. A Companion to Alexander Literature in the Middle Ages. Leiden \& Boston: Brill, 2011. Print. 